Acta Protozool. (2017) 56: 119-127

\title{
Peculiarities of Trypanosoma rangeli KP1(-) Strains Isolated from the Wild Rodent Phyllomys dasythrix (Santa Catarina, Brazil): Comparisons with T. rangeli KP1(+) strains and Trypanosoma lewisi (Kinetoplastea, Trypanosomatidae)
}

\author{
Maria A. SOUSA ${ }^{1,2}$, Barbara N. SANTOS ${ }^{1}$, Cristina CARVALHAL ${ }^{1}$, Mario STEINDEL ${ }^{3}$ \\ ${ }^{1}$ Coleção de Tripanossomatídeos, ${ }^{2}$ Laboratório de Toxoplasmose e outras Protozooses, Instituto Oswaldo Cruz, Fiocruz, Rio de \\ Janeiro, RJ, Brasil, ${ }^{3}$ Laboratório de Protozoologia, Departamento de Microbiologia, Imunologia e Parasitologia, Universidade \\ Federal de Santa Catarina, Florianópolis, SC, Brasil
}

\begin{abstract}
Two KP1(-) strains of Trypanosoma rangeli (SC-58, SC-61) isolated from the wild rodent Phyllomys dasythrix from Santa Catarina (Brazil) were compared with some KP1(+) reference stocks from different Latin America countries, and also with Trypanosoma lewisi. The strains were analyzed by some morphological and biological features, and by biochemical and molecular techniques. The mean total length (TL) of the bloodstream trypomastigotes of T. rangeli varied between 31.3-33.0 $\mu \mathrm{m}$, and those of $T$. lewisi (adult forms) was $28.2 \mu \mathrm{m}$, values within the variation known for each species. In T. rangeli $\mathrm{KP} 1(+)$ and $T$. lewisi, the nucleus was located in the anterior portion of the body, with nuclear indexes (NI) $\geq 1.2$, as typically described for both species. Differently, most trypomastigotes of the KP1(-) stocks presented $\mathrm{NI} \leq 1.0$. Another striking feature of the KP1(-) strains was their very fastidiously growth in axenic cultures when compared with the KP1(+) stocks and T. lewisi. Three isoenzyme loci (MDH, IDH and PGM) clearly distinguished T. rangeli and T. lewisi, and the distinction between the KP1(+) and KP1(-) strains was possible at MDH, PGM and GPI loci. All T. rangeli strains presented the typical $760 \mathrm{bp}$ amplicon derived from their KP2 minicircles. However, the KP3 products of the KP1(+) strains were a single large band ( $\sim 330 \mathrm{bp})$, whereas those of the KP1(-) had two distinct bands (350 and $300 \mathrm{bp}$ ). T. lewisi presented 700 and 400 bp amplicons, as previously reported. The peculiarities of $T$. rangeli isolates from $P$. dasythrix corroborate a possible speciation process within this taxon.
\end{abstract}

Key words: $\mathrm{KP} 1(+)$ and $\mathrm{KP1}(-)$ Trypanosoma rangeli strains, Trypanosoma lewisi, morphology, biology, isoenzymes, PCR products

\section{INTRODUCTION}

Trypanosoma rangeli Tejera, 1920 is a parasite of human beings, domestic and sylvatic mammals, widely distributed in the Latin America, being trans-

Address for correspondence: Maria Auxiliadora de Sousa, Laboratório de Toxoplasmose e outras Protozooses, Instituto Oswaldo Cruz, Fiocruz, Avenida Brazil 4365, 21040-900, Rio de Janeiro, RJ, Brasil. E-mail: msousaa@ioc.fiocruz.br mitted by triatomine bugs mainly of the genus Rhodnius. This species is harmless to their vertebrate hosts, but can be pathogenic for its insect vectors (Hoare 1972, D'Alessandro-Bacigalupo and Saravia 1992). Trypanosoma lewisi (Kent, 1880) is a non-pathogenic parasite of rats (mainly Rattus spp.) transmitted by fleas, being found throughout the world where these mammals occur. T. lewisi is the type-species of de subgenus Herpetosoma, which includes several species with a high degree of host-restriction, differently from $T$. rangeli 
(Hoare 1972, Molyneux 1976). The most common hosts of the Herpetosoma species are rodents and some lagomorphs, but $T$. lewisi (or T. lewisi-like) has been also reported in primates, including human beings, sometimes as opportunist infections (Johnson 1933, Maia-da-Silva et al. 2010, Sousa 2014). There is close resemblance between the bloodstream trypomastigotes of $T$. rangeli and the "adult" forms of $T$. lewisi, besides between their stages in axenic cultures (Hoare 1972; D'Alessandro 1976; Sousa 1999, 2014). Some phylogenetic studies validated only the inclusions of $T$. lewisi in the Herpetosoma subgenus (Maia-da-Silva et al. 2010) and placed T. rangeli within the T. cruzi clade (e.g., Hamilton et al. 2007) despite the lack of biological and morphological affinities between these species (Sousa 1999).

In 1991, Steindel et al. isolated a very peculiar T. rangeli strain (SC-58) from the wild rodent Phyllomys dasythrix (Santa Catarina Island, southern Brazil). It presented morphology and biological behavior typical of this species, but had uncommon isoenzyme patterns. Subsequently, Macedo et al. (1993) compared this strain together with another of the same origin (SC-61) with seven $T$. rangeli isolates from the Central and north part of South Americas by their DNA fingerprints and molecular hybridization patterns with specific nDNA and kDNA probes. A phenetic analysis of these results, as well as from isoenzyme and RAPD analyses (Steindel et al. 1994), evidenced two main distinct groups in T. rangeli, one of them including only the isolates SC-58 and SC-61. Macedo et al. (1993) also discovered the absence of KP1 minicircles in the SC-58 strain, a finding subsequently confirmed by Vallejo et al. (2002) in other strains from Santa Catarina, besides from other countries (Colombia and Panama). The stocks of T. rangeli were subsequently denoted as KP1(+) and KP1(-) according to the presence or absence of this minicircle class (Vallejo et al. 2002). Studies on the PCR products from the spliced-leader intergenic region (SL-IR) confirmed the dichotomy in $T$. rangeli and expanded the knowledge on their geographic distribution in the Latin America (Grisard et al. 1999a; Vallejo et al. 2003, 2015; Urrea et al. 2005, 2011; Salazar-Antón et al. 2009). Several authors reported associations between the two main $T$. rangeli groups and their regional vectors, besides their development pattern within these insects (Machado et al. 2001; Vallejo et al. 2003, 2015; Urrea et al. 2005, 2011; Salazár-Antón et al. 2009). Other authors, proposed the subdivision of $T$. rangeli into five lineages (A-E), and the SC-58 was classified in the lineage D (Maia-da-Silva et al. 2007, 2009) based on SL-IR and ribosomal gene sequencing. Some studies have associate the KP1(+) strains with the lineage A, and KP1(-) strains with C and D (Ocaña-Mayorga et al. 2015, Vallejo et al. 2015), but correlations between these genotypes are still lacking for several $T$. rangeli isolates.

In the recent decades, the literature on biochemical and molecular characterization of $T$. rangeli has greatly increased, this being accompanied by a drastic reduction of morphological and biological studies. Consequently, there are still gaps in our knowledge on $T$. rangeli, as some aspects of its life-cycle in vectors and vertebrate hosts, as well as in axenic cultures (Hoare 1972, Añez 1983, D’Alessandro-Bacigalupo and Saravia 1992, Grisard et al. 1999b, Sousa et al. 2008). However, nowadays it is possible to obtain new and consistent conclusions on living organisms by combining the above-mentioned approaches. In the present work, we compared some morphological and biological features of both KP1(-) strains isolated from $P$. dasythrix with those from some $\mathrm{KP} 1(+)$ reference stocks of $T$. rangeli from several Latin American countries, besides T. lewisi. Classical biochemical and molecular analyses were also performed to confirm their genetic differences.

\section{MATERIALS AND METHODS}

\section{Parasite strains}

All trypanosome stocks analyzed in the present work proceeded from the Trypanosomatid Collection at Oswaldo Cruz Institute, and are identified by their code-numbers (in parentheses). The KP1(-) strains of T. rangeli were: SC-58 (CT-IOC 270) and SC-61 (CT-IOC 272/349). The KP1(+) strains were: Macias (CT-IOC 273), Choachi (CT-IOC 271), H14 (CT-IOC 038), San Agustín (CT-IOC 282) and R1625 (CT-IOC 002). Most of these strains had been also classified in different lineages based on SL-IR and ribosomal gene sequencing (Maia-da-Silva et al. 2007), as follows: A (Macias, Choachi, San Agustín), C (R1625) and D (SC-58). Data on the origin of these isolates were described by Steindel et al. (1994) and on their identification as KP1(+) and KP1(-) are in Sincero et al. (2015).

The stock of $T$. lewisi used throughout this study was isolated by M. P. Deane (Deane strain) (Sousa 2014), and deposited in the Trypanosomatid Collection with two code-numbers: CT-IOC 009 (blood forms, experimentally infected rats) and CT-IOC 095 (axenic cultures).

\section{Morphological and biometrical studies}

These studies were performed on Giemsa-stained smears of bloodstream trypomastigotes of four T. rangeli strains (SC-58, SC61, Choachi and Macias) and T. lewisi (only adult forms), as seen under optical microscopy $(\times 1,000)$. Firstly, these stages were drawn with the aid of a camera lucida coupled to a microscope. Measurements (in centimeters) were taken directly on these drawings, and 
these values transformed into micrometers by a multiplication factor deduced from the size of a scale bar $(\mathrm{cm})$ corresponding to $10 \mu \mathrm{m}$, which was included in all drawing plates (Sousa et al. 2008). The blood smears with trypomastigotes of $T$. rangeli were provided by M. Steindel (Federal University of Santa Catarina), proceeding from experimentally infected mice. Those of $T$. lewisi were donated by N. Thomas (IOC, Fiocruz), proceeding from experimentally infected rats.

In the present study, the biometrical parameters chosen for comparisons were: total length (TL) of the parasite body (free flagellum included) and the nuclear index (NI) (Dias and Freitas 1943, Hoare 1972). Measurements of trypomastigotes were taken from the parasite posterior end $(\mathrm{P})$ to the middle of the nucleus $(\mathrm{PN})$, from the middle of nucleus to the anterior end (NA), and the free flagellum length (F) (see Fig. 1, SC-61). The parasite total length (TL) was determined by $\sum=\mathrm{PN}+\mathrm{NA}+\mathrm{F}$. The nuclear index $(\mathrm{IN}=\mathrm{PN} / \mathrm{NA})$ indicates the position of the nucleus in the trypanosome body, as follows: $\mathrm{NI}=1$, central nucleus; $\mathrm{NI}<1$, nucleus nearest the parasite posterior end; $\mathrm{NI}>1$, nucleus nearest the anterior end.

\section{Parasite growth in axenic cultures}

All comparative studies on the growth of T. rangeli and T. lewisi strains in axenic cultures were carried out using liver infusion-tryptose both (LIT) supplemented with $20 \%$ fetal calf serum (LIT-20) from the same bath. Cultures were begun by seeding $2.0 \times 10^{6}$ cells of each strain into $16 \times 150 \mathrm{~mm}$ screw-cap tubes containing $4 \mathrm{~mL}$ of medium and kept at $27.3^{\circ} \mathrm{C}\left( \pm 0.4^{\circ} \mathrm{C}\right)$. Before seeding, each stock had been twice passed (weekly intervals) in a biphasic medium (N.N.N. overlaid with LIT-20), and once in LIT-20. The cultures under study were examined on the $4^{\text {th }}, 7^{\text {th }}, 10^{\text {th }}, 13^{\text {th }}, 17^{\text {th }}$ and $20^{\text {th }}$ days for determining the number of cells $/ \mathrm{mL}$ using Neubauer hemocytometers. The arithmetic mean and maximum growth from each trypanosome stock were used to compare the isolates under study.

\section{Biochemical and molecular analyses}

For these analyzes, parasite cells were grown in LIT-20, harvest by centrifugation $\left(1,500 \mathrm{~g}, 15 \mathrm{~min}, 4^{\circ} \mathrm{C}\right)$, washed twice in salineEDTA (0.1 M, pH 8.0), and the pellets stored in nitrogen liquid until use.

The trypanosomes under study were compared by multilocus enzyme electrophoresis (MLEE) on agarose gels according to standard procedures, as described elsewhere. The stocks were tested for activity of five enzymatic loci: malate dehydrogenase (E.C.1.1.1.37; $\mathrm{MDH}$ ), isocitrate dehydrogenase (E.C.1.1.1.42; IDH), phosphoglucomutase (E.C.2.7.5.1; PGM), glucose phosphate isomerase (E.C.5.3.1.9; GPI) and malic enzyme (E.C.1.1.1.40; ME).

For polymerase chain reaction (PCR), the DNA from each species was extracted by the DNAzol method, as described elsewhere. The amplifications were performed using the primes 121 (5'-AAA TAA TGT ACG GG(T/G) GAG ATG CAT GA-3') and 122 (5'-GGT TCG ATT GGG GTT GGT GTA ATA TA-3'), which were described as $T$. cruzi-specific, but can also amplify kDNA minicircle sequences from other trypanosome species (Sousa et al. 2008, 2014). The PCR products from each isolate $(15-18 \mu \mathrm{l})$ were loaded onto the slots of $1.6 \%$ agarose gels, and electrophoresed at $70-73 \mathrm{~V}$, for $3 \mathrm{~h}$. Molecular size marker (100 bp DNA ladder) was included into the gels. After ethidium bromide staining, the gels were examined and photographed under ultraviolet light.

\section{RESULTS AND DISCUSSION}

\section{Morphological and biometrical studies}

The results of the biometry of the bloodstream trypomastigotes from $\mathrm{KP} 1(-)$ and $\mathrm{KP} 1(+)$ T. rangeli stocks, besides the "adult" forms $T$. lewisi, are presented in Table 1. All T. rangeli isolates studied herein presented TL (mean and ranges) within the variation reported by several authors for this species and the so-called T. saimiri (Pifano 1949, Groot et al. 1951, Deane and Damasceno 1961, Hoare 1972, D’Alessandro 1976, Miles et al. 1983, Ziccardi and Oliveira 1998). Likewise, the TL values of $T$. lewisi were also within the variation reported by Hoare (1972). Table 2 presents these findings. However, the TL values reported by Suárez et al. (2008) for some KP1(-) strains of T. rangeli strains from Rhodnius pallescens and $R$. colombiensis were not in accordance with our results and those from different authors (Table 2), suggesting either problems in the scale calibration used in the measurements, or that these stocks could belong to another $T$. rangeli-like species, as summarized by Hoare (1972).

The close resemblance between the bloodstream trypomastigotes of $T$. rangeli and the adult forms of $T$. lewisi has been largely confirmed in several publications, and among their peculiarities, the most remarkable one is the nucleus position at the anterior portion of the parasite body (NI $\geq 1.1$ ) (Pifano 1949, Groot et al. 1951, Hoare 1972, D'Alessandro 1976, Molyneux 1976, Miles et al. 1983, Guhl and Vallejo 2003, Maia-da-Silva et al. 2010, Sousa 2014). In the present study, this feature was confirmed in the blood trypomastigotes of the $\mathrm{KP} 1(+)$ strains of $T$. rangeli and in T. lewisi. However, most bloodstream forms of the KP1(-) strains (SC-58 and SC-61) presented NI $\leq 1.0$, since their nucleus was mainly central or placed in the posterior portion of the body (Table 1; Fig. 1). Interestingly, the finding of $T$. rangeli and $T$. rangeli-like stocks displaying bloodstream trypomastigotes with $\mathrm{NI} \leq 1.0$ had been only reported in isolates of wild vertebrates and triatomines from the Brazilian Amazon, including T. saimiri, which is considered a junior-synonym of T. rangeli (Ziccardi and Oliveira 1998) (Table 2). At present, it is unknown if $T$. saimiri and other T. rangelilike stocks from this region present KP1 minicircles, but several isolates from there were classified in the lineage B according to SL-IR and RNA gene sequencing (Maia-da-Silva et al. 2007, Vallejo et al. 2015). Recently, Sincero et al. (2015) proposed that they belong 


\section{KP1(-)}
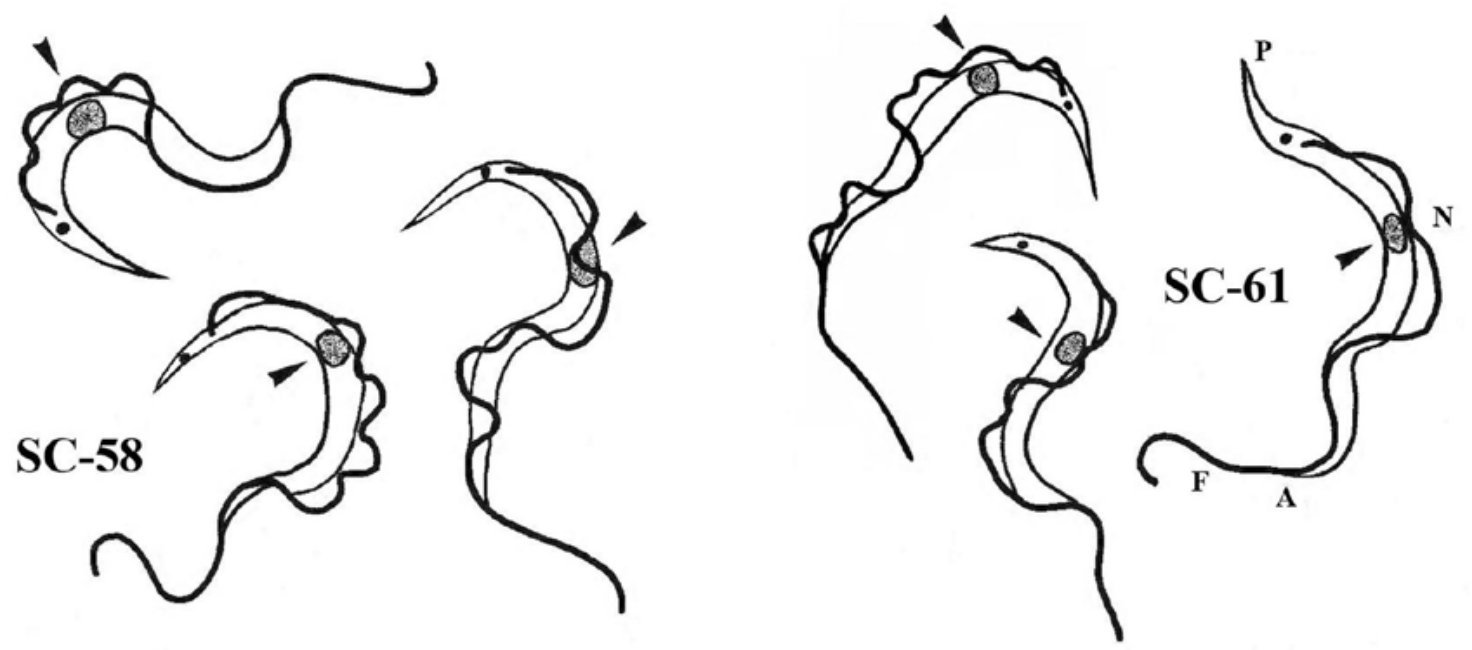

KP1(+)
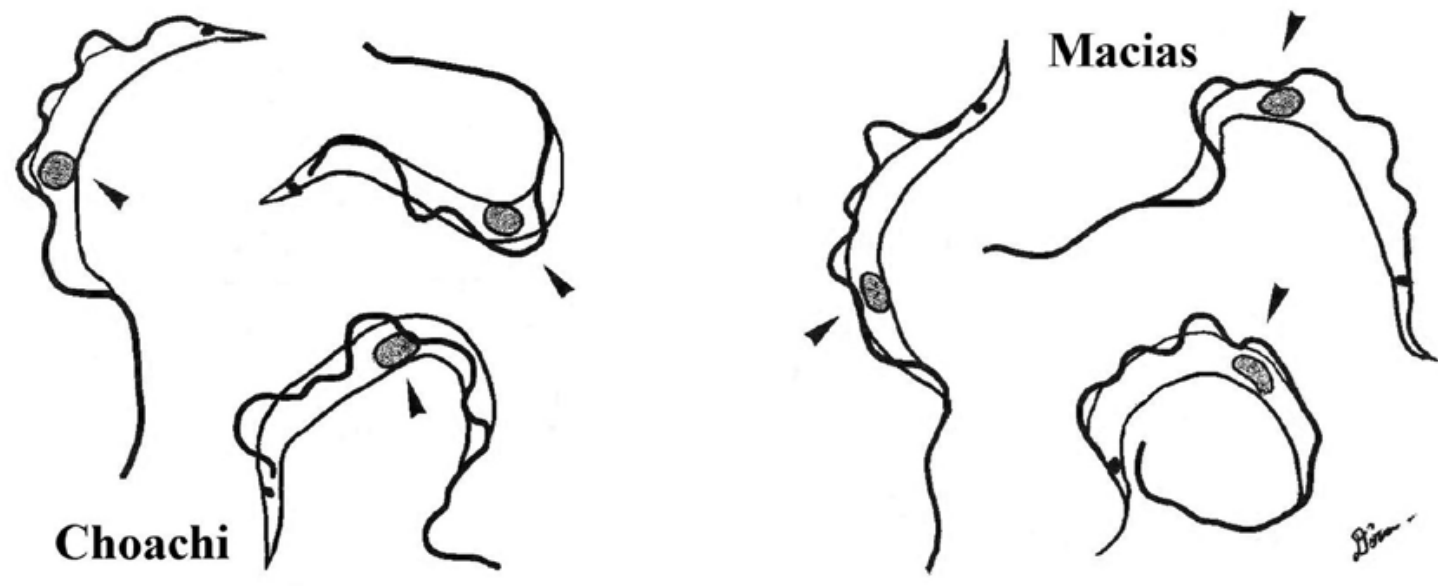

$10 \mu \mathrm{m}$

Fig. 1. Camera lucida drawings of representative bloodstream trypomastigotes of Trypanosoma rangeli KP1(-) and KP1(+) strains from experimentally infected mice by metacyclic trypomastigotes grown in DMEM medium. The position of the nucleus in each trypomastigote is indicated by arrowheads. Parasites were from Giemsa-stained smears of each strain, as seen under optical microscopy $(\times 1,000)$. In a trypomastigote of the strain SC-61 are indicated the reference points for taking measurements: anterior end (A), posterior end (P), nucleus (N) and free flagellum $(\mathrm{F})$.

to an ancestral group of $T$. rangeli, apart from $\mathrm{KP} 1(+)$ and KP1(-), then named Amazonian group.

\section{Parasite growth in axenic cultures}

Fig. 2 presents the results of the comparative study on the growth in axenic culture of $\mathrm{KP} 1(-)$ and $\mathrm{KP} 1(+)$ $T$. rangeli strains, besides $T$. lewisi. It is noteworthy, that the KP1(-) strains from P. dasythrix (SC-58 and
SC-61) were more fastidious than all the KP1(+) stocks examined, and to a lesser extent than T. lewisi, this indicating marked differences in their nutritional requirements. This finding suggests that the KP1(-) strains could be easy eliminated in mixed cultures with $\mathrm{KP} 1(+)$ $T$. rangeli stocks. We did not know another study that comparatively analyzed the growth of isolates of $T$. rangeli (with or without $T$. lewisi) in axenic cultures 
Table 1. Biometrical study of bloodstream trypomastigotes from Giemsa-stained smears of KP1(-) and KP1(+) Trypanosoma rangeli strains, and T. lewisi (adult forms). Biometrical parameters: TL (total length, flagellum included), and NI (nuclear index) according to Dias and Freitas (1943). Means, standard deviations and ranges (in parenthesis) are in $\mu \mathrm{m}(\mathrm{n}=30$, unless indicated). Percent of forms with NI $\leq$ 1.0 are also presented. The trypomastigotes of T. rangeli and T. lewisi were from experimentally infected mice and rats, respectively.

\begin{tabular}{|c|c|c|c|c|c|}
\hline \multirow{3}{*}{ Parameters } & \multicolumn{4}{|c|}{ Trypanosoma rangeli } & \multirow{3}{*}{$\begin{array}{l}\text { T. lewisi* } \\
\text { Deane }\end{array}$} \\
\hline & \multicolumn{2}{|c|}{ KP1(-) } & \multicolumn{2}{|c|}{$\mathrm{KP} 1(+)$} & \\
\hline & SC-58 & SC-61 & Choachi & Macias & \\
\hline $\mathrm{TL}(\mu \mathrm{m})$ & $\begin{array}{l}33.0 \pm 4.2 \\
(24.8-38.8)\end{array}$ & $\begin{array}{l}31.3 \pm 4.1 \\
(24.0-38.3)\end{array}$ & $\begin{array}{l}31.8 \pm 2.3 \\
(27.0-35.2)\end{array}$ & $\begin{array}{l}33.1 \pm 2.1 \\
(26.5-36.8)\end{array}$ & $\begin{array}{l}28.2 \pm 4.2 \\
(19.8-35.0)\end{array}$ \\
\hline $\mathrm{PN}(\mu \mathrm{m})$ & $\begin{array}{l}12.1 \pm 1.5 \\
(8.7-14.6)\end{array}$ & $\begin{array}{l}11.7 \pm 1.7 \\
(8.3-16.1)\end{array}$ & $\begin{array}{l}14.1 \pm 1.3 \\
(11.7-17.4)\end{array}$ & $\begin{array}{l}15.1 \pm 1.6 \\
(12.6-18.7)\end{array}$ & $\begin{array}{l}13.2 \pm 2.4 \\
(9.1-18.1)\end{array}$ \\
\hline $\mathrm{NA}(\mu \mathrm{m})$ & $\begin{array}{l}12.1 \pm 2.6 \\
(6.1-17.0)\end{array}$ & $\begin{array}{l}10.9 \pm 2.3 \\
(6.5-15.2)\end{array}$ & $\begin{array}{l}8.5 \pm 1.2 \\
(7.0-10.4)\end{array}$ & $\begin{array}{l}7.9 \pm 1.5 \\
(3.5-10.2)\end{array}$ & $\begin{array}{l}6.4 \pm 2.0 \\
(1.7-8.9)\end{array}$ \\
\hline NI (PN/NA) & $\begin{array}{l}1.0 \pm 0.3 \\
(0.6-1.9)\end{array}$ & $\begin{array}{l}1.1 \pm 0.3 \\
(0.7-2.0)\end{array}$ & $\begin{array}{l}1.7 \pm 0.3 \\
(1.2-2.2)\end{array}$ & $\begin{array}{l}2.0 \pm 0.6 \\
(1.4-4.7)\end{array}$ & $\begin{array}{l}2.5 \pm 1.8 \\
(1.3-8.5)\end{array}$ \\
\hline $\mathrm{NI} \leq 1.0(\%)$ & 60.0 & 56.6 & 0.0 & 0.0 & 0.0 \\
\hline
\end{tabular}

$\mathrm{NI}$ indicates the position of the nucleus in the trypanosome body, as follows. NI $=1$, central nucleus. NI $<1$, nucleus nearest the posterior end. NI $>1$, nucleus nearest the anterior end. The anterior end is that where the flagellum emerges. PN: distance from the parasite posterior end to the middle of the nucleus). NA: distance from the middle of nucleus to the parasite anterior end.

$(*) \mathrm{n}=15$.

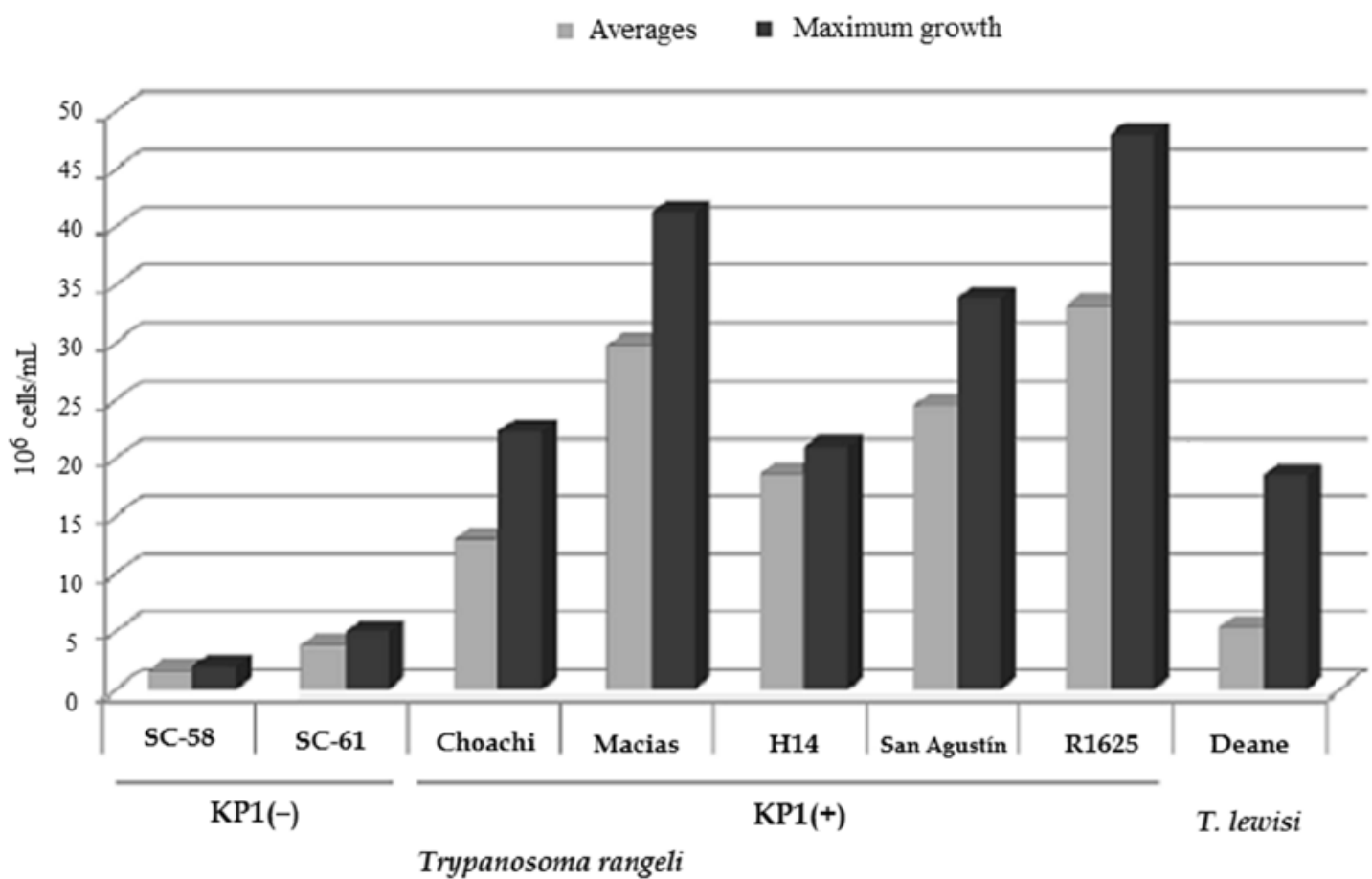

Fig. 2. Comparative growth in axenic cultures of Trypanosoma rangeli strains $[\mathrm{KP} 1(-)$ and $\mathrm{KP} 1(+)]$ and $T$. lewisi. Data $\left(10^{6}\right.$ cells $\left./ \mu \mathrm{L}\right)$ are the averages and the maximum growth from the values taken at the $4^{\text {th }}, 7^{\text {th }}, 10^{\text {th }}, 13^{\text {th }}, 17^{\text {th }}$ and $20^{\text {th }}$ days of cultivation in liver infusion-tryptose broth supplemented with $20 \%$ fetal calf serum (LIT-20) at $27.3 \pm 0.4^{\circ} \mathrm{C}$. 
124 M. A. Sousa et al.
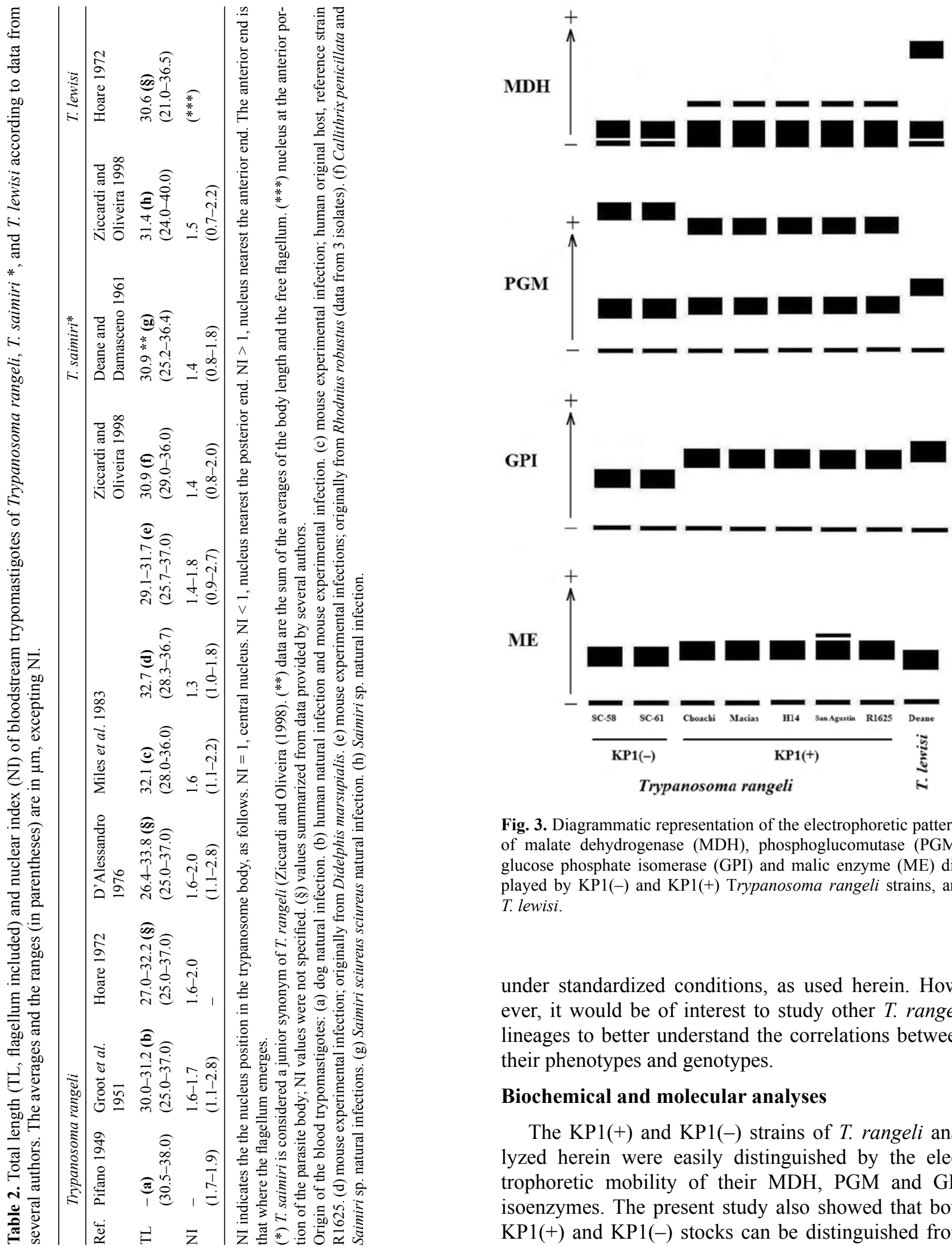

Fig. 3. Diagrammatic representation of the electrophoretic patterns of malate dehydrogenase (MDH), phosphoglucomutase (PGM), glucose phosphate isomerase (GPI) and malic enzyme (ME) displayed by KP1(-) and KP1(+) Trypanosoma rangeli strains, and T. lewisi.

under standardized conditions, as used herein. However, it would be of interest to study other $T$. rangeli lineages to better understand the correlations between their phenotypes and genotypes.

\section{Biochemical and molecular analyses}

The KP1(+) and KP1(-) strains of $T$. rangeli analyzed herein were easily distinguished by the electrophoretic mobility of their MDH, PGM and GPI isoenzymes. The present study also showed that both $\mathrm{KP} 1(+)$ and KP1(-) stocks can be distinguished from 


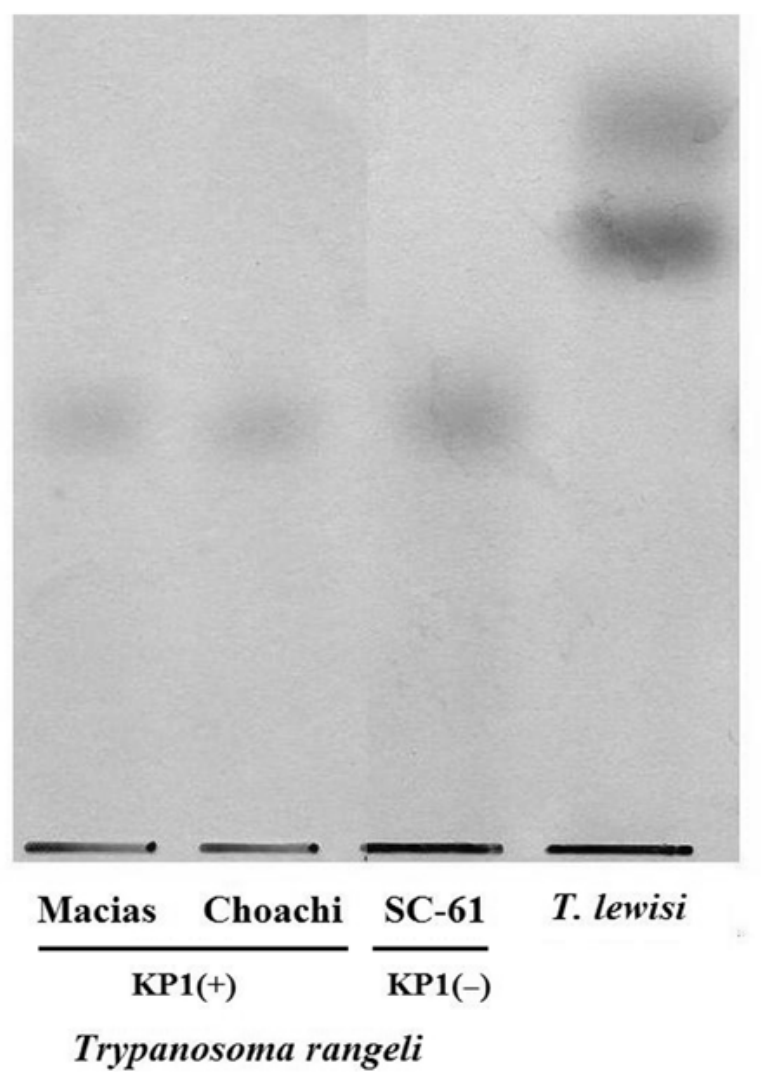

Fig. 4. Isoenzyme profiles at IDH locus presented by KP1(+) and KP1(-) Trypanosoma rangeli strains and T. lewisi.

T. lewisi by their MDH, PGM and IDH patterns. However, $T$. rangeli and $T$. lewisi displayed only discrete differences at the ME locus, the same occurring between the $\mathrm{KP} 1(+)$ strains and T. lewisi at the GPI locus. The Figs. 3 and 4 illustrate these results. Steindel et al. (1991, 1994) had also compared the isoenzyme patterns of the SC-58 strain with four $T$. rangeli strains (H8GS, H14, San Agustín and Macias) at the GPI, PGM, ME, besides ASAT (aspartate aminotransferase) and ALAT (alanine aminotransferase) loci, and they found that this strain was clearly distinct from the others.

Some authors had reported slight isoenzyme variation in T. rangeli isolates (Miles et al. 1983, Holguín et al. 1987), whereas others found heterogeneity (Kreutzer and Sousa 1981). These results can be derived from differences in the genotypes analyzed by them. As previously found by Macedo et al. (1993) in DNA fingerprints, and by Steindel et al. $(1991,1994)$ in MLEE and RAPD profiles, the main dichotomy of $T$. rangeli was confirmed herein, and also correlated with their $\mathrm{KP} 1(+)$ and KP1(-) groups (Sincero et al. 2015). However, the
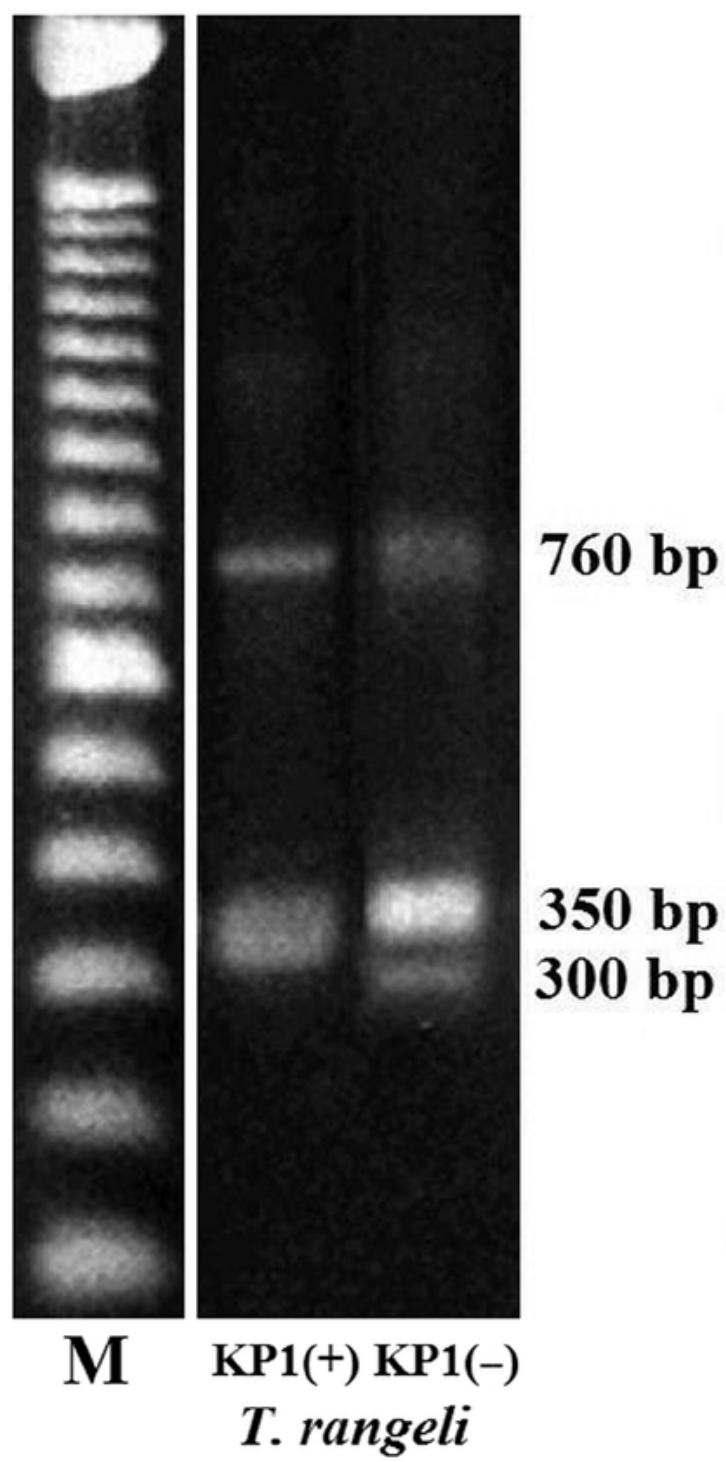

Fig. 5. kDNA minicircle amplicons presented by all KP1(+) and KP1(-) Trypanosoma rangeli strains examined in this study, and obtained by polymerase chain reaction using the primers 121/122. (M) molecular marker (100-bp DNA ladder).

strains of the lineages B and $\mathrm{E}$ have not been analyzed by these approaches.

Using the primers $121 / 122$ targeted to $T$. cruzi $\mathrm{kDNA}$ minicircle sequences, all $T$. rangeli strains analyzed presented their typical $760 \mathrm{bp}$ amplicon derived from the KP2 minicircles (Vallejo et al. 2002, Sousa et al. 2008). However, differences between the KP1(+) and KP1(-) strains were found in the products of their KP3 minicircles, as illustrated in Fig. 5. The former ones (Choachi, Macias, H14, San Agustín and R1625) dis- 
played a single large band ( $\sim 330 \mathrm{bp})$, while two distinct bands ( $\sim 350 \mathrm{bp}$, and another with $300 \mathrm{bp})$ were found the KP1(-) stocks (SC-58 and SC-61). These two amplicons were also seen in KP1(-) samples from $R$. ecuadoriensis analyzed by Ocaña-Mayorga et al. (2015; Fig. 1A). It is interesting to note that $T$. rangeli stocks from Rhodnius spp. (Pallescens lineage) were identified in the KP1(-) group and lineage $\mathrm{C}$, an association that has been proposed (Vallejo et al. 2015). However, the reference strain R1625 (human origin) was classified in the lineage C (Maia-da-Silva et al. 2007), although being KP1(+), as reported by Sincero et al. (2015) and confirmed by our results. Accordingly, it is necessary to identify (or review) the KP1 type of several T. rangeli strains, mainly those previously classified in the lineages B, C and E (Maia-da-Silva et al. 2007, 2009), in order to better establish the correlations between the groups obtained with distinct genotypic markers. Otherwise, as previously reported by Sousa (2014), the primers 121/122 generated two different amplicons for T. lewisi (400 and $700 \mathrm{bp}$ ), enabling its clear distinction from $T$. rangeli, besides $T$. cruzi .

\section{CONCLUSIONS}

As far we know, $\mathrm{KP} 1(+)$ and $\mathrm{KP} 1(-)$ T. rangeli strains have not yet been compared by their morphological and biological features, and the present paper evidenced other peculiarities of the SC-58 and SC-61 isolates from $P$. dasythrix from Santa Catarina Island. Recent molecular studies (Sincero et al. 2015) point to a subdivision within the KP1(-) group, which corroborate the uniqueness of these isolates, besides others from wild Panstrongylus megistus from the same region (Vallejo et al. 2002, 2015). This may reflect a process of speciation within $T$. rangeli, as advanced by some authors (Macedo et al. 1993, Guhl and Vallejo 2003, Vallejo et al. 2003), closely associated to the vector lineages (Machado et al. 2001; Vallejo et al. 2002, 2015; Urrea et al. 2005, 2011; Maia-da-Silva et al. 2007; Salazar-Antón et al. 2009; Barreto-Santana et al. 2015; Sincero et al. 2015). At present, with so much available knowledge on $T$. rangeli genetic diversity, we question whether the KP1(-) group from southern Brazil could be a subspecies. Otherwise, we emphasize the importance of better knowing other wild stocks, as those from the lineages B and E (Maia-da-Silva et al. 2007, 2009), by their morphological and biological features as well, either to verify whether they actually can be identified as $T$. rangeli or belong to another similar species, as those cited by Hoare (1972) and D'Alessandro-Bacigalupo and Saravia (1992). However, accounting the extensive variability of $T$. rangeli throughout the Latin America, only after more comparative studies, using different approaches and reference stocks from distinct origins, it will be possible to conclude whether there are one or more subspecies/species included in this taxon.

Acknowledgments. To Mrs. Sheila Medeiros dos Santos Pereira and Cláudia de Sá Xavier for collaborating in this work.

\section{REFERENCES}

Añez N. (1983) Studies on Trypanosoma rangeli Tejera, 1920. VI. Developmental pattern in the haemolymph of Rhodinus prolixus. Mem. Inst. Oswaldo Cruz 78: 413-419

Barreto-Santana D., Santos-Schuernker L., Fonseca A. R., Gurgel-Gonçalves R., Cuba-Cuba C. A. (2015) Susceptibility of different Rhodnius species (Hemiptera, Reduviidae, Triatominae) to a Brazilian strain of Trypanosoma rangeli (SC58/KP1-). Biomédica 35: 81-89

D’Alessandro A. (1976) Biology of Trypanosoma (Herpetosoma) rangeli, Tejera, 1920. In: Biology of the Kinetoplastida, vol. I, (Eds. W. H. R. Lumsden, D. A. Evans). Academic Press, New York, 327-403

D’Alessandro-Bacigalupo A., Saravia N. G. (1992) Trypanosoma rangeli. In: Parasitic Protozoa, $2^{\text {nd }}$ ed., vol. 2, (Eds. J. P. Kreier, J. R. Baker). Academic Press, San Diego, 1-54

Deane L. M., Damasceno R. G. (1961) Tripanosomídeos de mamíferos da região amazônica. II. Tripanosomas de macacos da Zona do Salgado, Estado do Pará. Rev. Inst. Med. Trop. São Paulo 3: 61-70

Dias E., Freitas L. (1943) Introdução ao estudo biométrico dos hemoflagelados do gênero Schizotrypanum. I. Introdução, material e técnica, problema e métodos estatísticos. Mem. Inst. Oswaldo Cruz 38: $427-436$

Grisard E. C., Campbell D. A., Romanha A. J. (1999a) Mini-exon gene sequence polymorphism among Trypanosoma rangeli strains isolated from distinct geographical regions. Parasitology 118: 375-382

Grisard E. C., Steindel M., Guarneri A. A., Eger-Mangrich I., Campbell D. A., Romanha A. J. (1999b) Characterization of Trypanosoma rangeli strains isolated in Central and South America: an overview. Mem. Inst. Oswaldo Cruz 94: 203-209

Groot H., Renjifo S., Uribe C. (1951) Trypanosoma ariarii, n. sp., from man, found in Colombia. Am. J. Trop. Med. 31: 673-691

Guhl F., Vallejo G. A. (2003) Trypanosoma (Herpetosoma) rangeli Tereja, 1920 - an updated review. Mem. Inst. Oswaldo Cruz 98: 435-442

Hamilton P. B., Gibson W. C., Stevens J. R. (2007) Patterns of coevolution between trypanosomes and their hosts deduced from ribosomal RNA and protein-coding gene phylogenies. Mol. Phylog. Evol. 44: 15-25

Hoare C. A. (1972) The Trypanosomes of Mammals. A Zoological Monograph. Blackwell Scientific Publications, Oxford, 749 pp.

Holguín A. F., Saravia N. G., D’Alessandro A. (1987) Lack of enzyme polymorphism in Trypanosoma rangeli stocks from syl- 
vatic and domiciliary transmission cycles in Colombia. Am. J. Trop. Med. Hyg. 36: 53-58

Johnson P. D. (1933) A case of infection by Trypanosoma lewisi in a child. Trans. R. Soc. Trop. Med. Hyg. 26: 467-468

Kreutzer R. D., Sousa O. E. (1981) Biochemical characterization of Trypanosoma spp. by isozyme electrophoresis. Am. J. Trop. Med. Hyg. 30: 308-317

Macedo A. M., Vallejo G. A., Chiari E., Pena D. J. (1993) DNA fingerprinting reveals relationships between strains of Trypanosoma rangeli and Trypanosoma cruzi. In: DNA Fingerprinting: State of Science, (Eds. S. D. J. Pena, R. Chakraborty, J. T. Epplan, A. J. Jeffreys). Birkhäuser-Verlag Basel, 321-329

Machado P. E., Eger-Mangrich I., Rosa G., Koerich L. B., Grisard E. C., Steindel M. (2001) Differential suceptibility of triatomines of the genus Rhodnius to Trypanosoma rangeli strains from different geographical origins. Int. J. Parasitol. 31: 632634

Maia-da-Silva F., Junqueira A. C. V., Campaner M., Rodrigues A. C., Crisante G., Ramirez L. E., Caballero Z. C. E., Monteiro F. E., Coura J. R., Añez N., Teixeira M. M. G. (2007) Comparative phylogeography of Trypanosoma rangeli and Rhodnius (Hemiptera: Reduviidae) supports a long coexistence of parasite lineages and their sympatric vectors. Mol. Ecol. 16: 3361-3373

Maia-da-Silva F., Marcili A., Lima L., Cavazzana M. Jr., Ortiz P. A., Campaner M., Takeda G. F., Paiva F., Nunes V. L. B., Camargo E. P., Teixeira M. M. G. (2009) Trypanosoma rangeli isolates of bats from Central Brazil: genotyping and phylogenetic analysis enable description of a new lineage using spliced-leader gene sequences. Acta Trop. 109: 119-207

Maia-da-Silva F., Marcili A., Ortiz P. A., Epiphanio S., Campaner M., Catão-Dias J. L., Shaw J. J., Camargo E. P., Teixeira M. M. G. (2010) Phylogenetic, morphological and behavioural analyses support host switching of Trypanosoma (Herpetosoma) lewisi from domestic rats to primates. Infect. Genet. Evol. 10: $522-529$

Miles M. A., Arias J. R., Valente S. A. S., Naiff R. D., Souza A. A., Povoa M. M., Lima J. A. N., Cedillos R. A. (1983) Vertebrate hosts and vectors of Trypanosoma rangeli in the Amazon Basin of Brazil. Am. J. Trop. Med. Hyg. 32: 1251-1259

Molyneux D. H. (1976) Biology of trypanosomes of the subgenus Herpetosoma. In: Biology of the Kinetoplastida, vol. 1, (Eds. W. H. R. Lumsden, D. A. Evans). Academic Press, New York, 285-325

Ocaña-Mayorga S., Aguirre-Villacis F., Pinto C. M., Vallejo G. A., Grijalva M. J. (2015) Prevalence, genetic characterization, and 18S small subunit ribosomal RNA diversity of Trypanosoma rangeli in triatomine and mammal hosts in endemic areas of Chagas disease in Ecuador. Vector-Borne Zoon. Dis. 15(12): $732-742$

Pifano F. (1949) Estado actual de las investigationes en Venezuela sobre una nueva trypanosomiasis humana de la region neotropica producida por el Trypanosoma rangeli. Arch. Venezol. Patol. Trop. Parasit. Med. 1: 135-152

Salazar-Antón F., Urrea D. A., Guhl F., Arévalo C., Azofeifa G., Urbina A., Blandón-Naranjo M., Sousa O. E., Zeledón R., Vallejo G. A. (2009) Trypanosoma rangeli genotypes association with Rhodnius prolixus and $R$. pallescens allopatric distribution in Central America. Infect. Genet. Evol. 9: 1306-1310

Sincero T. C. M., Stoco P. H., Steindel M., Vallejo G. A., Grisard E. C. (2015) Trypanosoma rangeli displays a clonal population structure, revealing a subdivision of KP1(-) strains and the ancestry of the Amazonian group. Int. J. Parasitol. 45: 225-235
Sousa M. A., Fonseca T. S., Santos B. N., Santos-Pereira S. M., Carvalhal C., Hasslocher-Moreno A. M. (2008) Trypanosoma rangeli Tejera, 1920 in chronic Chagas' disease patients under ambulatory care at the Evandro Chagas Clinical Research Institute (IPEC-Fiocruz, Brazil). Parasitol. Res. 103: 697-703

Sousa M. A. (1999) Morphobiological characterization of Trypanosoma cruzi Chagas, 1909 and its distinction from other trypanosomes. Mem. Inst. Oswaldo Cruz 94 (Suppl I): 205-210

Sousa M. A. (2014) On opportunist infections by Trypanosoma lewisi in humans and its differential diagnosis from T. cruzi and T. rangeli. Parasitol. Res. 113: 4471-4475

Steindel M., Pinto C. J. C., Toma H. K., Mangia R. H. R., Rodrigues R. R., Romanha A. J. (1991) Trypanosoma rangeli (Tejera, 1920) isolated from a sylvatic rodent (Echimys dasythrix) in Santa Catarina Island, Santa Catarina State: first report of this trypanosome in southern Brazil. Mem. Inst. Oswaldo Cruz 86: 73-79

Steindel M., Dias-Neto E., Pinto C. J. C., Grisard E. C., Menezes C. L. P., Murta S. M. F., Simpson A. J. G., Romanha A. J. (1994) Randomly amplified polymorphic DNA (RAPD) and isoenzyme analysis of Trypanosoma rangeli strains. J. Eukaryot. Microbiol. 41: 261-267

Suárez Q. Y., Carranza J. C., Clavijo J. A., Vallejo G. A. (2008) Pleomorfismos en cepas de Trypanosoma rangeli aisladas de Rhodnius colombiensis y R. pallescens. Rev. Tumbaga 3: 63-80

Urrea D. A., Carranza J. C., Cuba-Cuba C. A., Gurgel-Gonçalves R., Guhl F., Schofield C. J., Triana O., Vallejo G. A. (2005) Molecular characterisation of Trypanosoma rangeli strains isolated from Rhodnius ecuadoriensis in Peru, $R$. colombiensis in Colombia and $R$. pallescens in Panama, supports a co-evolutionary association between parasites and vectors. Infect. Genet. Evol.: 5: 123-129

Urrea D. A., Guhl F., Herrera C. P., Falla A., Carranza J. C., CubaCuba C., Triana-Chávez O., Grisard E. C., Vallejo G. A. (2011) Sequence analysis of the spliced-leader intergenic region (SL-IR) and random amplified polymorphic DNA (RAPD) of Trypanosoma rangeli strains isolated from Rhodnius ecuadoriensis, $R$. colombiensis, $R$. pallescens and $R$. prolixus suggests a degree of co-evolution between parasites and vectors. Acta Trop. 120: 59-66

Vallejo G. A., Guhl F., Carranza J. C., Lozano L. E, Sánchez J. L., Jaramillo J. C., Gualtero D., Castañeda N., Silva J. C., Steindel M. (2002). KDNA markers define two major Trypanosoma rangeli lineages in Latin-America. Acta Trop. 81: 77-82

Vallejo G. A., Guhl F., Carranza J. C., Moreno J., Triana O., Grisard E. C. (2003) Parity between kinetoplast DNA and mini-exon gene sequences supports either clonal evolution or speciation in Trypanosoma rangeli strains isolated from Rhodnius colombiensis, R. pallescens and R. prolixus in Colombia. Infect. Genet. Evol. 3: 39-45

Vallejo G. A., Suárez Y., Olaya J. L., Gutiérrez S. A., Carranza J. C. (2015) Trypanosoma rangeli: un protozoo infectivo y no patógeno para el humano que contribuye al entendimiento de la transmisión vectorial y la infección por Trypanosoma cruzi, agente causal de la enfermedad de Chagas. Rev. Acad. Colomb. Cienc. Ex. Fis. Nat. 39(150): 111-122

Ziccardi M., Oliveira R. L. (1998) Morphological features of trypanosomes from squirrel monkeys from the Brazilian Amazon. Mem. Inst. Oswaldo Cruz 93: 45-55

Received on $10^{\text {th }}$ May, 2017, revised on $19^{\text {th }}$ July, 2017, accepted on $20^{\text {th }}$ July, 2017 